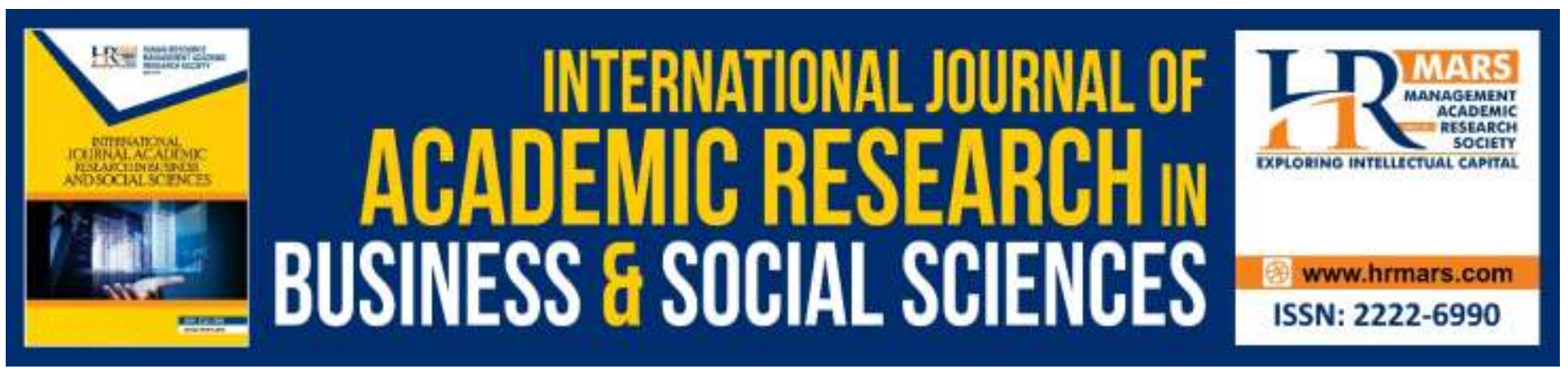

\title{
Willingness to Pay to Conserve Tenualosa toli (Terubok)
}

\author{
N. A. Bakeri, A. M. Dayang Affizzah, A. M. Abdullah and R. Ashraf-Roszopor
}

To Link this Article: http://dx.doi.org/10.6007/IJARBSS/v10-i14/7363

DOI:10.6007/IJARBSS/v10-i14/7363

Received: 12 April 2020, Revised: 16 May 2020, Accepted: 23 June 2020

Published Online: 27 June 2020

In-Text Citation: (Bakeri et al., 2020)

To Cite this Article: Bakeri, N. A., Affizzah, A. M. D., Abdullah, A. M., \& Ashraf-Roszopor, R. (2020). Willingness to Pay to Conserve Tenualosa toli (Terubok). International Journal of Academic Research in Business and Social Sciences, 10(14), 61-69.

Copyright: @ 2020 The Author(s)

Published by Human Resource Management Academic Research Society (www.hrmars.com)

This article is published under the Creative Commons Attribution (CC BY 4.0) license. Anyone may reproduce, distribute, translate and create derivative works of this article (for both commercial and non-commercial purposes), subject to full attribution to the original publication and authors. The full terms of this license may be seen

at: http://creativecommons.org/licences/by/4.0/legalcode

Special Issue: WSTI2018 - Issues and Trends on Education, Science and Technology, 2020, Pg. 61 - 69 http://hrmars.com/index.php/pages/detail/IJARBSS JOURNAL HOMEPAGE

Full Terms \& Conditions of access and use can be found at http://hrmars.com/index.php/pages/detail/publication-ethics 


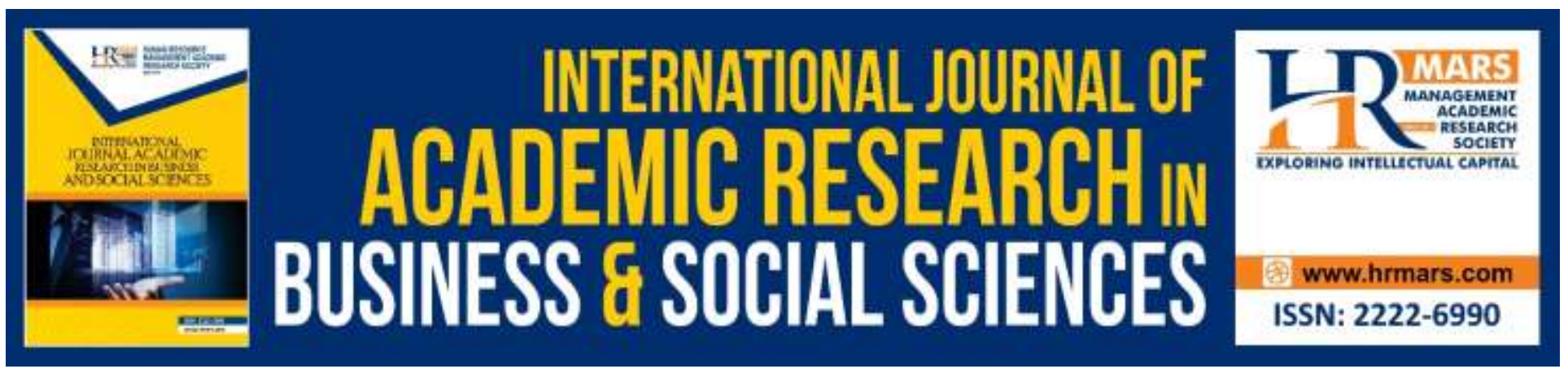

\title{
Willingness to Pay to Conserve Tenualosa toli (Terubok)
}

\author{
N. A. Bakeri ${ }^{1}$, A. M. Dayang Affizzah², A. M. Abdullah³ and R. \\ Ashraf-Roszopor ${ }^{4}$ \\ ${ }^{1,2,4}$ Department of Economics, Universiti Malaysia Sarawak, Malaysia, ${ }^{3}$ Department of Agriculture, \\ Universiti Putra Malaysia \\ Email: ashrafroszopor@gmail.com
}

\begin{abstract}
Over the year, the population of local terubok (Tenualosa toli) is being threatened due to overexploitation. Terubok is one of the famous and important commercially fish in Malaysia which only found in Sarawak rivers. Nowadays, the landing of local terubok are very limited and difficult to obtain since 1980s. Environmental goods like terubok has a value to society, however, it is difficult to obtain and express these economic values in monetary terms. One of the methods that commonly used to evaluate non-market valuation which is Contingent valuation method (CVM) was used in this study to estimate the willingness-to-pay (WTP) of local communities to conserve terubok. A dichotomous choice contingent valuation method (DC-CVM) in single bound formulation was employed in this study. The general objective of this study is to examine the monetary value that local people are willing to pay to conserve terubok in Sarawak. The result shows that WTP of Yes decreases as the price of the offer increases. Result indicates that respondents are willing to pay at an average of RM31 per annum for sustainability of Terubok.
\end{abstract}

Keywords: Contingent Valuation, Environmental Goods, Economic Value, Willingness to Pay.

\section{Introduction}

The world's ecosystems provide a huge variety of useful services that enhance human welfare (Pagiola, Bishop \& Von Ritter, 2004). Natural ecosystem provides valuable commodities such as animals, edible plants, medicinal products, construction materials and also clothing. Aesthetic or cultural benefits provided by natural ecosystems, including scenic views and recreation opportunity offers many benefits that can be classify as a public good where everyone can used it freely without any barrier. However, the existence of public goods creates a problem resulting negative externalities affecting all user such as destruction of environmental resources. Public goods problem often closely related to the "free-rider" and over-usage problems in which people are not paying for the good and continue to access it, resulting ecosystem nowadays in under tremendous pressures where most of the forest ecosystems have been converted to other uses, wetlands are being drained and coral reef are destroyed. 
In this study, terubok provides a good illustration of a public good for natural ecosystems that are currently under tremendous pressures. Over the years, terubok is being exploited especially for its roe and meat which the spawning adult fish is targeted. The population of terubok is being threatened because of the over-exploitation (Rahim, Tumiran, Yuzine \& Husaini, 2014). Until these days, the number of local terubok are still very limited and very difficult to obtain. Due to the high demand of terubok, many imported terubok that came from India and Myanmar entering the market. In Sarawak, there are only two species of terubok that can be found in Sarawak water which is tenualosa toli and tenualosa macrura. However, this study are mainly focusing on tenualosa toli or locally known as river terubok because nowadays terubok are scarce and yet it has a high market value. Terubok is one of the famous and important commercially fish in Malaysia and it is also famous among tourist with the name of terubok ikan masin, where it is highly demanded in local market for its meat and eggs (Blaber, Milton, Chenery \& Fry, 2003). Tourist especially came from West Malaysia would not miss the opportunity to buy it. In fact, terubok ikan masin is listed in Sarawak Top 10 Iconic food as posted by Sarawak Tourism Board in its 2012 survey. However, tenualosa macrura or locally known as sea terubok are less favorable because of the taste of its meat are less tasty than river terubok.

Terubok has a value to society, however, it is hard for us to measure it in the monetary value. The main purpose of this study is to measure the value of terubok that local communities in Kuching willing to pay in order to conserve terubok population through a survey using contingent valuation method (CVM). The CVM method is widely used today as a toll for assessing the value of public, in particular environmental good. It is a stated preference method for eliciting economic value of goods and services that are not available in markets. As this method are well known, it has potential advantages as compared with other methods, but also have severe potential weaknesses. Among these are (1) the possibility of "free rider" incentives to misstate preferences, (2) potential systematic biases of valuation due to lack of understanding with the object to be valued, (3) influences from the interviewer, and (4) hypothetical nature of the issue at stake, since payment is not actually required.

\section{Materials and Method}

The study was conducted in Kuching area using a random sampling. 1300 respondent were interviewed and only 1203 are used for the purpose of this analysis. The potential respondents were asked about their willingness to pay in conserving terubok, as a traditional CVM study, with no assumption that payment would actually be required. Potential respondents were approached and asked if they were willing to participate in this study.

Structured closed-ended questions were used in the survey. The interviews were done in faceto-face approach to the respondents. The questionnaire was written in Bahasa Melayu because all the respondents are mostly not using English as their mother tongue language. The first part of the questionnaire asking respondent with a general ("warm-up") question comprises of background of the study. This aimed at making the respondent comfortable with participating in the survey and answering questions. Respondents level of knowledge about the current status of terubok in Sarawak river was also assessed. Respondents were also asked to state their perception towards the conservation of terubok. The second part is about the valuation process contained the hypothetical market for eliciting respondents WTP. The respondents were asked about their WTP to conserve terubok by considering their current income and expenses and what motivate them to pay for the conservation. This part of questionnaire has different in the amount of bid which make it into five 
sets of questionnaires. After answering YES or NO, an open question will be asked about the maximum amount they willing to pay for the conservation. This section was created to identify the characteristics of paying and the mean value of WTP. Last but not least, the information regarding respondents' socio-economics and demographic characteristics such as age, gender, occupation, races, education level and average monthly income will be asked in the last part of the questionnaire. The data obtained from the interview were analyzed using the SPSS statistic version 22. Descriptive analysis such as mean and frequency were used to obtain information about the socio demographic, economic profiles and respondents WTP.

\section{Theoretical Framework}

A dichotomous choice contingent valuation method (DC-CVM) in single bound formulation was used in the survey to measure the WTP of respondent. Typically, in contingent valuation studies, the standard approaches have been used to elicit respondents WTP is DC method where the valuation question is such a take-it-or-leave-it where it is more likely to reflect the actual world market decisions which individuals are confronted with. In addition, DC reveals itself to be less vulnerable to strategic bidding behavior of open-ended elicitation format. Theoretical approach of DC elicitation format was firstly proposed by Cameron (1988) that used in his paper where WTP is modelled as a latent variable which an alternative to a discrete choice problem (Hanemann, Loomis \& Kanninen, 1991). Random Utility Theory is the background which connects CVM a response to the problem of utility maximization. Under this theoretical framework, the answers of the respondents from the scenario given allows to evaluate the individual demand on the quality of the environment with appropriated econometric tools, thus, there would be a change underlying welfare. Based on this framework, respondents were asked whether they would be willing to pay certain amounts of money to get a change in the quality of the environment as for the conservation of terubok in Sarawak rivers. The individual's willingness to pay (WTP) reveals information about the value placed on the terubok.

Respondents were asked to answer YES or NO if they are willing to pay a given amount (bid) for the goods or services.

"By considering your current income and expenses, would you willing to pay RM $\mathbf{x}$ in the future to conserve terubok?"

Where $x$ ranged from RM5.00 to RM25.00, which represent the price of bid for conserving terubok. After answering (YES/NO), they are not given another bid. Instead, we will ask an open question about the maximum amount they are willing to pay for the conservation. However, there are limitation in applying single bound formulation but we also considered the difficulties in using double bound formulation. We believe that single bound provides an opportunity to estimate the respondent willingness to pay towards the sustainability of terubok fishery.

Since there is no study has determined the bid price for willingness to pay of respondents for conservation of terubok in this field, it is difficult to determine the bid amount for the study. The bid amount was estimated from the pilot studies where it was conducted to determine the appropriateness of bid price in CVM weather the bid is too low or too high. Many amendments have been done after performing a pilot test. This phase is important in order to eliminate any potential issues in constructing the final questionnaire set. Respondent were selected randomly from Kuching district. 
A systematic approach was done by offering the first bidding RM5, RM10 to the second respondent, RM15 to third and so on. The cycle was then repeated in this order until the end of the survey. Moreover, to avoid bias, the survey distributes randomly without taking into account who has the highest income, will get highest price of bid. Respondents also been given a scenario as for general knowledge before answering bidding question.

The scenario read as:

"Tenualosa toli or locally known as river terubok is one of the famous products among tourists that came to Kuching, Sarawak. Tourists especially came from the peninsula would not miss the opportunity to buy terubuk. However, Sarawak faced the problem with extinction of terubuk population. There are various effort that has been done by government to ensure the sustainability of terubuk. One of it is by implementing a closed season which is by controlling the capture of terubuk and build a terubuk research center in Lingga, Sri Aman, which is aiming to increase the number of terubuk population in Sarawak river. However, in the future, the efforts by the government itself is not enough to ensure the sustainability of this fish industry. All parties need to work together to keep and sustain this invaluable fish that is not available in other States in Malaysia from extinction. This is very important to educate the society on the importance of conserving terubuk. Thus, contributions from you in conserving terubuk will ensure the sustainability of terubuk and become one of the uniqueness in Sarawak."

\section{Results}

\section{Respondents' Profile}

Table 2 displays the summary of the respondents' profiles. The minimum and maximum age of respondents is at 18 to 69 years old respectively. In term of income, the lowest and highest of income is at RM100 and RM8,000 respectively. By gender, the majority of respondents were female (52.1\%). Most of the respondents are Malay races (67.3\%) and followed by Iban races (15.4\%). More than half of the respondents are employed (85.4\%) and the remaining are self-employed (2.5\%) and pensioner (12.1\%). In term of education background, most of the respondents had completed tertiary education (52.5\%) while the others are only completed primary (3.3\%) and secondary (44.2\%) education level. 
INTERNATIONAL JOURNAL OF ACADEMIC RESEARCH IN BUSINESS AND SOCIAL SCIENCES

Vol. 10, No. 14, Special Issue: WSTI2018 - Issues and Trends on Education, Science and Technology, 2020, E-ISSN: 2222-6990 @ 2020 HRMARS

Table 2: Profile of respondents

\begin{tabular}{cccccc}
\hline \hline & & $\mathbf{N = 1 2 0 3}$ & & & \\
\hline \hline Variable & & Frequency & \% & Min & Max \\
\hline Age & & & & 18 & 69 \\
Income & Male & 576 & 47.9 & 100 & 8000 \\
Gender & Female & 627 & 52.1 & & \\
& Malay & 810 & 67.3 & \\
Race & Iban & 185 & 15.4 & \\
& Bidayuh & 95 & 7.9 & \\
& Chinese & 113 & 9.4 & \\
Employment status & Employed & 1027 & 85.4 & \\
& Self-employed & 146 & 12.1 & \\
& Pension & 30 & 2.5 & \\
Education & Primary & 40 & 3.3 & \\
& Secondary & 532 & 44.2 & \\
& Tertiary & 631 & 52.5 & \\
\hline
\end{tabular}

\section{Factors Influencing Willingness to Pay}

Explanatory factor analysis (EFA) was conducted in this study in order to investigate the factors that influencing willingness to pay. As can be seen in Table 3, the Kaiser-Meyer-Olkin Measure of Sampling Adequacy (KMO) and Bartlett's test measure of sampling adequacy was used to examine the appropriateness of Factor analysis. The KMO is 0.918 greater than 0.50 which shows that the sample is adequate and the approximate of Chi-square is 10,733.561 with 253 degrees of freedom, which is significant at 0.01 level of significance, hence, it is considered as an appropriate technique for further analysis of the data.

Table 3: KMO and Barlett's Test

\begin{tabular}{lll}
\hline Kaiser-Meyer-Olkin Measure of Sampling Adequacy & 0.918 \\
Barlett's Test of Sphericity & Approx. Chi-Square & 10733.561 \\
& df & 253 \\
& Sig. & .000 \\
\hline
\end{tabular}

Factor analysis has identified five key factors that influence attitude of local communities to pay for conservation. Table 4 shows the categorized factors. Five factors were extracted explaining $58.51 \%$ of the variance. This was decided based on eigenvalues greater than 1 and cumulative variance as well as the inspection of the scree plot. Factors were obliquely rotated using Varimax rotation. All the factors can be used for the further analysis because they had a high reliability value (Table 4) where Nunally (1978) suggests that the acceptable values are minimum of 0.7 alpha value.

Table 4: Factors influencing willingness to pay

\begin{tabular}{lccccc}
\hline Factors & Labelled as & Eigenvalue & \% of Variance & $\begin{array}{c}\text { Cumulative \% of } \\
\text { Variance }\end{array}$ & Reliability \\
\hline Factor 1 & Economy & 7.626 & 33.155 & 33.155 & 0.842 \\
Factor 2 & Commercial & 2.092 & 9.095 & 42.25 & 0.805 \\
Factor 3 & Conservation & 1.563 & 6.796 & 49.046 & 0.728 \\
Factor 4 & Regulation & 1.158 & 5.037 & 54.082 & 0.707 \\
Factor 5 & Employment & 1.019 & 4.428 & 58.511 & 0.785 \\
\hline
\end{tabular}




\section{Response to Bid}

This section reports the willingness of respondents to pay sum of the money for conservation of terubok. Figure 1 depicts that the response of saying YES (74.5\%) is high as compared to response saying NO (25.5\%). However, the probability of answering 'YES' will be reduced if the bid amount increased while the probability of answering 'NO' will increase if the bid amount increased. In this study, respondents were given five different prices of bid: RM5; RM10; RM15; RM20; RM25. Figure 1 reveals the number of responses to the five different prices of bid. The five different prices of bid were determined by the pilot studies. Most of the respondents (214) agreed to pay the lowest bid which is RM5. On the other hand, only 139 of respondents are willing to pay when the price reached RM25. From Table 5, most of the respondents (46.8\%) wanted to pay because they want to go towards the conservation and preservation of terubok for future generations. Among the other motivations for willingness to pay were they want to help the local communities who earn income from terubok (40\%) and they feel responsible in maintaining the ecosystem resources (35.8\%).

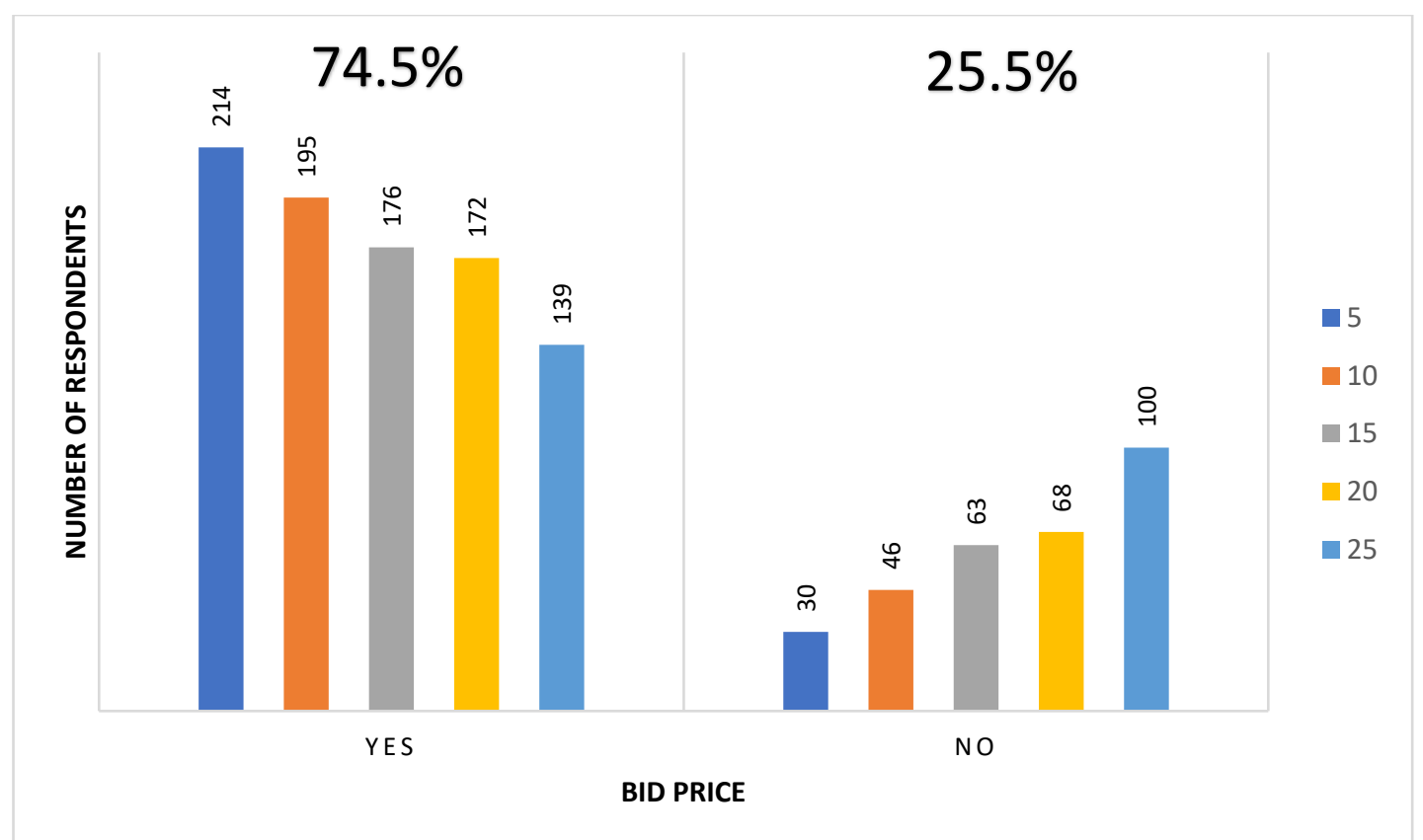

Figure 1: Number of responses to the bid

Table 5: Main motivations for Willingness to pay

\section{Motivation}

Response (\%)

1. I want to conserve and preserve terubok for future generations.

46.8

2. I want to help the local communities who earn income from terubok.

40.0

3. It give me self-satisfaction from paying.

18.0

4. I feel responsible in order to maintain ecosystem resources.

35.8

\section{Empirical Results of Logit Models}

Table 6 shows the regression results for logit models. Based on the estimations produced, socioeconomics variables such as Bid Price, Income, Malay, Factor 1 (Economy) and Factor 3 
(Conservation) were found to be important in the WTP estimations. It could be seen that the 'Bid Price' variable was significant at $1 \%$ level. The sign was negative, which means that the bidding price was highly significant and have a negative effect on the probability of a respondents saying 'Yes'. It shows that under hypothetical market, as offered bid price increases, the probability of saying 'Yes' decreases among respondents. Respondents reject the offered price as it increases and this is in line with the law of demand where the quantity demanded of a good decrease when its price increases. Income variable found to be significant at $5 \%$ level of significance with a positive sign. This means that as their income increases, they were willing to pay higher for the conservation as compared to the respondents with lower income. Using a dummy variable, the exponent value of Malay variables is 3.08. It shows that Malay are willing to pay 3.08 times higher than other races (Iban, Bidayuh, Chinese). Factor 1 (Economy) and Factor 3 (Conservation) was significant at $1 \%$ and $5 \%$ level respectively with a positive coefficient indicating that respondents who responded higher for "Economy" and "Conservation" factors were willing to pay more for the conservation than the respondents who responded less towards the factors. The model chi-squared value of 140.988 and is statistically significant at $p<0.001$. For the models the value Nagelkerke $R$ square value is 0.163 which describe that the amount of variation in the dependent variable clarified by the models. Furthermore, the logit models correctly classified $74.5 \%$ cases.

Table 6: Regression result for logit models.

\begin{tabular}{lcc}
\hline \multicolumn{1}{c}{ Variables } & Coefficient & t-values \\
\hline Constant & 2.865 & 0.254 \\
Bid Price & -0.077 & $0.010^{* * *}$ \\
Income & 0.000140 & $0.000^{* *}$ \\
Malay & e: 3.08 & $0.172^{* * *}$ \\
Factor 1 (Economy) & 0.210 & $0.069^{* * *}$ \\
Factor 3 (Conservation) & 0.37 & $0.077^{* *}$ \\
\hline Log Likelihood & & 1225.551 \\
Chi squared & & 140.988 \\
Nagelkerke R square & & 0.163 \\
Percentage correct & & $74.5 \%$ \\
\hline
\end{tabular}

\section{Mean Value of WTP}

The mean willingness to pay of respondents was derived from the following equations;

$$
V W T P=\left(ß_{0}+\beta_{I N C} * I N C+ß_{M A L A Y} * M A L A Y+ß_{F 1} * F 1+ß_{F 3} * F 3 / ß_{B I D}\right.
$$

Where, $\beta_{0}, \beta_{I N C} \beta_{\text {MALAY, }} \beta_{F 1}, \beta_{F 3}$ and $\beta_{B I D}$ are estimated parameters for constant term, income, malay, economy, conservation and bid price. Based on the estimation of WTP values, the calculated mean of WTP is MYR31, where its indicates that respondents are willing to pay at an average of MYR31 per annum for sustainability of terubok. MYR20,996,300 is the value of terubok that communities in Kuching willing to pay for the conservation. Table 7 shows a detailed summary of the exact values in MYR. 


\section{Table 7: Value of Willingness to Pay}

Mean

Maximum

Minimum

Population in Kuching (2015)

Value of Willingness to Pay (VWTP)
MYR31.00

MYR61.00

MYR8.00

677,300

(Source: Sarawak Fact \& Figures 2015)

MYR20,996,300.00

\section{Conclusions and Implications}

CVM is a unique method that can used to estimate economic values for all kinds of ecosystem and environmental services such as terubok. This study found evidence that local communities in Kuching are willing to pay more than the bid which range from RM5 to RM25. By employing the logit model, it is estimated that local communities willing to pay about MYR31 per annum for sustainability of terubok. This indicates that perhaps there will be a high support from the local if the intervention as described in the scenario will be implemented in this area. The main motivations for local communities' WTP are, most of them want to conserve and preserve terubok for the future generations. They believe that, if there is no proper intervention to be implemented on conserving terubok, it will extinct and forgotten by time. Moreover, from paying this, they can help the local communities indirectly who earn income from terubok. From here, it is crucial to have an awareness among the local communities on how importance of conserving terubok. This study has proof that the local are willing to pay for the conservation. The value of terubok itself shows how valuable terubok are among local communities in Kuching. However, the existence of public goods can lead to potential market failure resulting destruction of terubok population. It is suggested that the government or public sector improve the outcome of completely free markets. In order to implement this policy, government plays an important role to collect the fund from the communities for sustainability of terubok and find a right channeled for those money to circulate for the goodness of terubok. Furthermore, it is better to have more study on terubok for both side (user and non-user) to measure the overall market size and market's WTP for terubok among communities in Sarawak.

\section{References}

Bishop, R. C., \& Heberlein, T. A. (1979). Measuring values of extra-market goods: Are indirect measures biased? American Journal of Agricultural Economics. 61(5): 926-930.

Blaber, S. J. M., Milton, D. A., Chenery, S. R., \& Fry, G. (2003). New insights into the life history of Tenualosa ilisha and fishery implications. Am. Fish. Soc. Symp, 35. 223-240.

Hanemann, M., Loomis, J. B., \& Kanninen, B. (1991). Statistical efficiency of double-bounded dichotomous choice contingent valuation American Journal of Agricultural Economics, 73(4): 1255-1263.

Nunnaly, J. C. (1978). Psychometric theory ( $2^{\text {nd }}$ ed). New York: McGraw-Hill.

Rahim, K. A. A., Tumiran, M. H., Long, S. M., Yuzine, E., \& Husaini, A. A. S. A. (2014). The status of tenualosa toli in the southwest coast of Sarawak, Malaysia. Kuroshio Science. 8(1). 39-44.

Sarawak Fact \& Figures. (2015). State Planning Unit Chief Minister's Department. 